\title{
Tax Portfolio Optimization of the Hotel Business Entity Based on Tax Control Criteria
}

\author{
E.N. Yalunina ${ }^{1}$, I.V. Frolova ${ }^{2}$, T.V. Matytsyna ${ }^{2}$, and T.G. Pogorelova ${ }^{2}$ \\ ${ }^{1}$ Ural State University of Economics, 620144 Ekaterinburg, Russia \\ ${ }^{2}$ Southern Federal University, Rostov-on-Don, Russia
}

\begin{abstract}
Tax evasion is quite widespread in the hotel business activities in Russia. This fact does harm not only to the Russian economy as tourism is becoming one of the dynamically developing industries, but also to business entities since the lack of financial visibility contributes to internal thefts in these companies. Regular changes in the tax legislation associated with the growth of tax burden are taken hard by the enterprises of the hotel industry. This problem has become the most acute due to the fact that often companies involved into the hotel business falsify the key figures of financial and economic activity for the purpose of hiding the results of commercial activity in order to reduce or completely avoid paying taxes. The successful operation of the hotel business requires an appropriate tax management system. Tax portfolio development for the hotel business entity can become both a means of further business development and a source of onerous expenses. One of the key factors affecting the composition and amount of the tax portfolio is the use of tax alternatives. The main research goal of this study is to develop scientific and practical recommendations on risk-oriented management of the hotel business tax portfolio through the use of tax portfolio criteria. According to the goal, such objectives have been set and realized in the article as definition of institutional basis of tax control, a research of risk-oriented approach to tax portfolio management and identification of tax risks for any hotel business entity based on tax portfolio criteria.
\end{abstract}

\section{Introduction}

Nowadays the hotel business development has become very popular as a trend in Russia. It does the groundwork for competition, which puts before the hotels new requirements to improve and introduce new approaches to doing business. So, there is a need for a rapid response to changing consumer priorities.

In Russia there are a number of problems of hotel business development that must be given top priority to, such as

- business facilitation to attract additional sources for investing in the material and technical facilities;

- enacting laws specifying tax payments which would take into account features of the hotel business sector; 
- bringing the existing laws and regulations for the subjects of the Russian hotel business into compliance with international requirements and operating practice of similar enterprises in other countries;

- concept development of financial and economic support for hotels by federal and local authorities;

- development of mechanisms to promote hotels workload increase at the state level and active advertising of Russian tourist product abroad.

Solving these problems will help create conditions to provide concessional lending to the subjects of the hotel business and favorable tax regime for investors; to reduce tax burden for the hotel business and take into account some specific features of costs for services. These measures will increase the amount of investment in construction and development of hotel business. Moreover, the funds received due to the optimization of the tax portfolio of the hotel business can become the real source of investment.

Tax portfolio is an instrument by which the required ratio of the goals of economic entities and the state can be achieved, which is unattainable from the position of a particular tax, and is possible only when analyzing them together. The implementation of tax portfolio management system is subordinated to the interests of ensuring the stability and profitability of the hotel business entity.

Changes in the tax legislation associated with the growth of tax burden have a painful effect on hotel business, especially small business. The practice of developed economies is to provide small businesses with alternative tax options. Tax alternatives is the possibility for a business entity, including a hotel, to choose the legal form of business organization with corresponding taxation regime, tax benefits, preferences, deductions, and etc. avoiding institutional traps. The calculation and analysis technique is based on categories and methods of financial management.

Baseline study of the above mentioned issues and development of practical recommendations for the hotel business entities is becoming a challenging issue.

\section{Institutional Foundations of Tax Control}

The main legal document regulating taxation in Russia is the Tax Code of the Russian Federation (RF Tax Code). The tax control is regarded as the activities of authorized bodies to supervise taxpayers, tax agents, fees and insurance payers on their fulfillment of obligation to pay taxes. [1, ch.14].Tax control activities may include:

Inventory. It is conducted to verify the data reliability of taxpayer documents as well as to clarify other circumstances relevant to the fulfillment of the tasks of tax audit [1, Ch. 13, Art. 89].

Be summoned to appear as a witness. Tax authorities have the right to call any individual for giving evidence that may be relevant to circumstances important for the implementation of tax control.

Interrogation. Sometimes when conducting on-site tax audits, the witness is questioned in order to report any circumstances relevant to the implementation of tax control [1, art. 90].

Inspection. Tax authorities have the right to inspect any objects of taxation, regardless of their location, manufacturing, storage, trading and other premises and territories used by a taxpayer for getting income [1, art. 91, 92].

Discovery of documents. Tax authority official conducting tax audit has the right to demand the necessary documents from the auditee for verification [1, art. 93, 93.1].

Seizing documents is carried out in order to identify the violations of the Tax Law and find sufficient evidence of it [1, Art. 94]; 
Expert engagement may be necessary when conducting on-site tax inspections on a contract basis that assumes an expert involvement.

Expert Review. An expert is entitled to bring any conclusions about the circumstances he was not previously asked questions but relevant to the case in the course of expert examination.[1, art. 95]

Interpreter engagement may be necessary to participate in the activities for the implementation of tax control on a contract basis, as shown in Figure 1. [1, Art. 97]

\begin{tabular}{|c|c|}
\hline $\begin{array}{l}\text { article } 97 \text { of the tax } \\
\text { code }\end{array}$ & - engaging an interpreter \\
\hline $\begin{array}{l}\text { article } 95 \text { of the tax } \\
\text { code }\end{array}$ & $\begin{array}{l}\text { - expert examination; } \\
\text { - obtaining an expert opinion }\end{array}$ \\
\hline $\begin{array}{l}\text { article } 94 \text { of the tax } \\
\text { code }\end{array}$ & - seizure of documents and object \\
\hline $\begin{array}{l}\text { art. } 93,93.1 \text { of the } \\
\text { tax code }\end{array}$ & - discovery of documents \\
\hline $\begin{array}{l}\text { art. } 91,92 \text { of the tax } \\
\text { code }\end{array}$ & -inspection \\
\hline $\begin{array}{l}\text { article } 90 \text { of the tax } \\
\text { code }\end{array}$ & $\begin{array}{l}\text { - interrogation; } \\
\text {-call as a witness }\end{array}$ \\
\hline $\begin{array}{l}\text { article } 89 \text { of the tax } \\
\text { code }\end{array}$ & • inventory \\
\hline
\end{tabular}

Fig. 1. Elements of Tax Control [13]

Article 87 of the Tax Code in Russia states that tax inspections can be divided into inoffice audit and on-site examination/field audit. Field audit are complex or special, as well as planned and out-of-plan. Field inspection may be carried out for one or several types of taxes. Tax authorities are not entitled to conduct more than two on-site tax inspections of the same taxpayer for the same tax within the same period. (Afanasenko A.N., 2015) In recent years the approach to the organization of tax control has been changed with the emphasis on a comprehensive analysis of financial and economic activities resulting in transition to a riskbased control. In this regard, the Federal Tax Service (FTS) has developed the concept of planning field tax audits [3] providing new approach to a system of selecting sites for field tax audits. To assess the integrity of taxpayers such benchmarks as data on the tax burden and field profitability are used: those whose indicators are lower than the average in the industry are recognized as suspicious and may be included in the audit plan. Thus, taxpayers are able to assess the risk of an on-site tax audit independently according to the criteria developed by the Federal Tax Service of Russia. They will allow the taxpayer to stay in "tax stability" area. A taxpayer who does not meet these criteria will most likely be included in the on-site tax audit plan.

Subjects of tax law are not free to choose their counterparties. The overwhelming majority of tax norms are strict orders, rigidly regulating the limits of permitted and proper behavior for business entities. The legal nature of tax communications is marked by a significant specialty which arises from their public legal nature and the state's constitutional duty to ensure an equal tax burden and protection of rights, freedoms and legitimate interests of economic entities. That stipulates the use of imperative method of tax regulation. The freedom to choose the subjects of tax law is related to the availability of direct regulatory and legal requirements of the legislation on taxes and fees.

The institute of tax alternatives, which is a set of legal provisions that give taxpayers the option to choose from two or more tax preferences or objects of taxation, attracts wide attention in the tax-legal doctrine (Satterthwaite E, 2016). 
You can classify one-sided, two-sided and multilateral tax alternatives according to the number of participants involved in the decision- making. In addition, tax alternatives are further subdivided into "alternatives that concern taxpayers with coinciding interests and tax alternatives that affect taxpayers with divergent interests" (Cauble E., 2013).

In addition, tax alternatives are classified into backward-looking tax elections and forward-looking tax elections (Cauble E., 2013). In the first case, the taxpayer decides on the results of the tax period that has already passed when all information on the legal consequences of the alternative choice is available to the taxpayer at the time of the relevant decision-making. Prospective alternatives suggest a choice of tax election that is to be implemented in the future.

The provision of tax alternatives indicates the desire of the legislator to more actively introduce default rules in tax legislation. The use of default rules allows the stakeholders to choose the optimal taxation regime, utilizes the powerful motivational potential of individuals and stimulates their entrepreneurial activity. In the end, harmonization of public and private interests is ensured and stable tax law order is formed.

\section{Risk-Oriented Aproach to Managing Tax Portfolio}

Among the criteria for conducting a field tax audit, comparison of the taxpayer tax burden with the average level of tax burden for economic entities in a particular industry (type of economic activity) plays a domineering role. So, according to the Concept of planning onsite tax inspections for hotel activities, the average industry tax burden was $9.5 \%$ in 2016 , compared to $9 \%$ in 2014 and 2015 . The tax burden is calculated as the ratio of the amount of taxes paid according to the FTS data and the company turnover (revenue) according to the Federal Service for National Statistics (FSNS). In addition, we consider the profitability indicator based on some accounting records along with the level of profitability for a particular sphere of activity.

Profitability is a relative indicator of economic efficiency. It reflects the efficiency level of using material, labor, financial and other resources of the organization. The coefficient of profitability is calculated as the ratio of profit to assets.

The indicators of profitability can be divided into two groups:

1) return on sales shows the profit per ruble earned. Usually it is calculated as the ratio of net profit (after taxing) to the amount of sales in cash for the same period;

2) return on assets is calculated as the ratio of profit to average assets value of the organization, i.e. the indicator from the Statement of financial results is divided by the average value of the final indicator from the Balance Sheet.

Return of sales is an indicator of the company's pricing policy and its ability to control costs. It is also used to assess the operational efficiency of the organization.

Return on assets is an indicator of the profitability and efficiency of the organization's activities, saved from the impact of borrowed funds volume. It is used to compare the effectiveness of organizations in the same industry and is calculated using the following formula:

$R a=P / A$,

Where $R a$ is return on assets;

$P$ is profit for certain period of time;

$A$ is the average value of assets for the period.

The return on assets $(\mathrm{Ra})$ and the return on sales calculated according to the data of the FSNS of the Russian Federation for hotel activities in 2016 amounted to 6.1\%. In 2015 this figure was $5.8 \%$. The return indicator shows that the subjects of hotel business which profitability is $10 \%$ below than average in the industry will fall under the tax control. 
Another area of concern is organizations involved in financial and economic activities that bear losses for two or more years. In accordance with civil law, the purpose of any commercial organization is gaining profit that is not just income, but the growth of property as a result of their activities.

Financial losses without tendencies to redeem or decrease over several tax periods are the most likely the sign of distortion of performance indicators (most often for incomplete reporting of business results). Despite the outlined tendency to reduce the number of unprofitable enterprises their share in the total number of legal entities is quite large. According to the FSNS of the Russian Federation, in 2016 it decreased by $6.6 \%$ and amounted to $26 \%$ including the activity of hotels and restaurants that amounted $30,1 \%$ ( $39,3 \%$ in 2015 respectively ). [12]

Tax portfolio management of the hotel business entity is based on the optimization of taxation based on the introduction of tight limits on tax burden, profitability and loss ratio of the organization with regard to these indicators disclosed in the Concept of Planning Field Tax Inspections. The processes of harmonization of the organization's tax portfolio are related to the need to personify the company's tax burden for the purpose of stable and competitive development of the economic entity within the existing national tax system (Frolova I.V., Matytsyna T.V., Pogorelova T.G., Likhatskaya E.A.). Tax portfolio design means to determine the composition of its constant part and the variable, consisting of tax payments, which are subject to a complex of legitimate methods of tax optimization as it is shown in Figure 1.

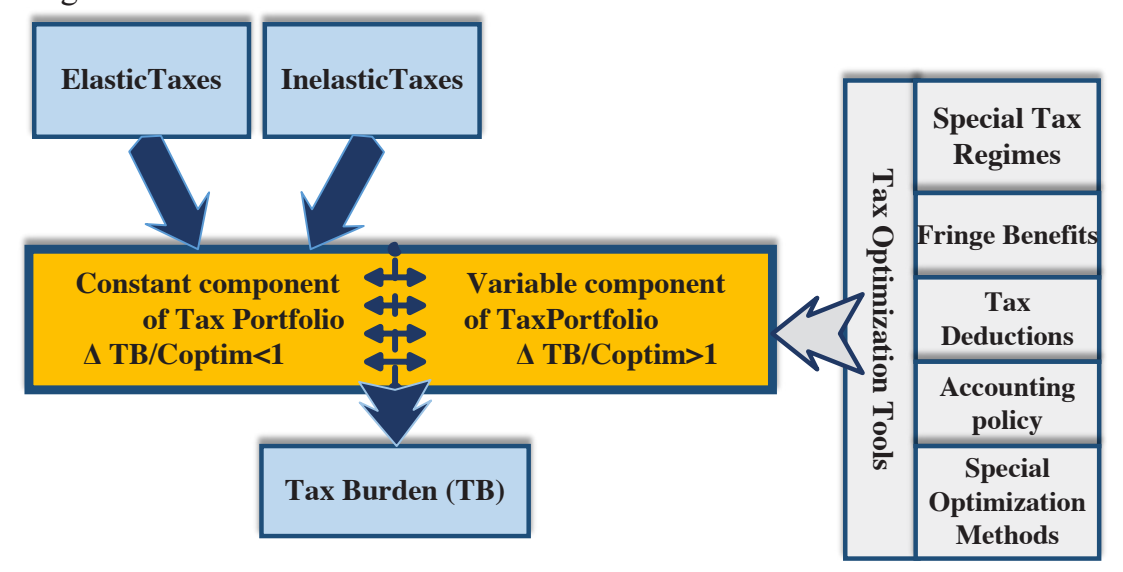

Fig. 2. Flows that form the tax portfolio of business entities [11]

Figure 2 reflects the structure of a company tax portfolio which consists of a constant and variable parts containing elastic (affected by a change in the revenue volume) and inelastic taxes. The constant and variable parts of the tax portfolio are defined as the relationship between changes in the tax burden, due to the use of tools for tax portfolio optimizing, and costs changes aimed at tax optimization including possible penalties of controlling authorities. If this ratio is less than unity and greater than zero, the tax should be attributed to the constant part. If it is greater than unity, the tax should be attributed to the variable part.

Tax portfolio management means regulation the value of the variable part, the share of which in the total portfolio value can be from zero and tend to unity. It is important not to cross the line between optimization of taxation and its minimization, when the positive effect is easily changed to the opposite, by imposing penalties. (Frolova I.V., Pogorelova T.G., 2016) 
Tax burden as the main economic indicator of the tax portfolio is a financial instrument that can be calculated. The absolute value of the tax burden of an economic entity is defined as the difference between constant and variable parts of the tax portfolio:

$\mathrm{TB}=$ Con.TP - Var.TP, (2)

Where TB - is the absolute value of the tax burden of an economic entity;

Con.TP - the value of the constant part of the tax portfolio;

Var.TP - the value of the variable part of the tax portfolio.

Within the scope of commercial activities every legal body and private customer regulates their tax portfolio by any available means. Authorities in some way contribute to this process, annually placing the average tax burden by industry which is one of the criteria for conducting on-site inspections of economic entities on the official website of tax service. Thus, the tax portfolio is one of the tools that help the economic entity provide income stability at minimum risk. One of the factors affecting the structure and amount of tax portfolio is the use of tax alternatives. The tax alternatives are interpreted as potentially possible methods of tax optimization. Tax alternatives can be classified into legal ones, i.e. state established opportunities to optimize tax portfolio of economic entities (benefits, deductions, tax holidays and other tax preferences) and illegal, as well as managerially proved and managerially groundless. (Frolova I.V., Pogorelova T.G., 2016)

Tax alternatives stimulating entrepreneurial activity, carrying out patronage activities, the level of education allow to admit that tax portfolio optimization is a legitimate, manageriallybased use of tax alternatives by any economic entity.

Organization's tax portfolio analysis, clarification of its structure, its external and internal determinants allow to consider the relation of the tax burden and tax risks of the organization, to take into account the composition of tax obligations, determine the amount of the tax potential and the nature of tax alternatives necessary for effective management of tax and financial risks of the organization.

\section{Tax Portfolio Optimization for the Subject of Hotel Business}

Keeping and maintenance of hotels, hostels and other areas for temporary residence is a rather specific type of business. The hotel complex is closely connected with the branches of business tourism and recreation; it represents a significant role in the country's economy: it participates in the production of GDP, creates jobs for the population, forms the basis for middle class development, reacts quickly to changes in the economic situation, allowing to smooth out the differences in economic development, etc.

The main problems of hotel market development in Russia are

- to create favorable conditions for investment attractiveness;

- to settle the issues of setting tax payments norms which would take into account the peculiar features of any business field;

- to bring the existing regulation acts in accordance with the international requirements and operation practice of similar enterprises abroad;

- to develop the concept of financial and economic support of enterprises by federal and local authorities;

- to develop mechanisms to facilitate hotels workload increase supported by the state and to advertise Russian tourist product abroad, etc.

There is a direct dependence of business success on a number of external factors: the level of infrastructure development, tourist and business attractiveness of the region, and even climate and season.

In order to manage the hotel's tax portfolio as a segment of financial planning it is recommended to follow the logic keeping within the law rather than a temporary gap in legislation. It is not recommended to minimize each tax separately; their management should 
be carried out in a complex way. Tax portfolio optimization means to establish an interests balance between the representatives of business and the state with respect to the tax charges payable.

Tax portfolio management in the current activity of the hotel business entity must be an ongoing process. The source of information on the amount of the constant part of the tax portfolio is data on taxes which are reflected on account 68 "Calculations on taxes and fees" to determine the operational tax burden. Personal income tax (PIT) also forms the tax portfolio of the organization in spite of the fact that individuals are payers. It is necessary to exclude the amount of tax deductions for value-added tax (VAT) from the total amount of taxes.

The constant part of the tax portfolio of the hotel business entity also includes compulsory insurance contributions reflected in account 69 "Social Security and Support Calculations", but they are not taken into account when calculating the organization's tax burden according to the instructions of the tax service representatives.

Using the account data of a subject of the hotel business the following is established: constant part of the hotel's tax portfolio without insurance premiums (Table 1) and proceeds from the sale of hotel services in the 1 st quarter.

Table 1. The constant part of the hotel's tax portfolio for the first quarter

\begin{tabular}{|c|c|c|}
\hline $\begin{array}{c}\text { The composition of the constant part } \\
\text { of the tax portfolio }\end{array}$ & Account & $\begin{array}{c}\text { Amount, } \\
\text { thousand } \\
\text { rubles. }\end{array}$ \\
\hline PIT & 68.1 & 151 \\
\hline VAT & 68.2 & 3433 \\
\hline income tax & 68.4 & 272 \\
\hline * Compiled by the authors & 3856 \\
\hline
\end{tabular}

Sale revenues from the hotel services for the 1st quarter including VAT is 22505 thousand rubles, to calculate the tax burden VAT is removed from this amount. Tax deduction (2483 thousand rubles) will be a component of the variable part of tax portfolio.

The current tax burden (TB) of the hotel for the 1st quarter, including the current variable part of the tax portfolio, is defined as the ratio of tax amount paid and revenues: TB $=((151$ $+3433-2483+272) /(22505-3433)) * 100=7.2 \%$.

The profitability of the hotel services sold is also an important criterion of risk assessment. Along with the tax burden, it is calculated according to the turnover-balance sheet data generated for the period analyzed.

The profitability of sales is calculated as the ratio of net profit (1434 thousand rubles) for a certain period to the amount of sales in monetary terms for the same period:

Profitability of sales $=1434 /(22505-3433) * 100=7.5 \%$.

Having calculated the key indicators of the analysed entity of the hotel business, it is necessary to compare them with the minimum values provided by the federal tax service. So, as it was mentioned above, for the economic entity which main economic activity is the activity of hotels and restaurants, the average industry tax burden for 2016 amounted $9.5 \%$, and the profitability of sales was $6.1 \%$.

Comparing the received value of the current tax burden of the hotel business entity and the tax burden according to the data published by the Federal Tax Service, it becomes obvious that the organization is at risk of an on-site tax audit. The tax burden index is 2.3 percentage points below the average in the industry while the profitability of sales is above the average in the industry by 1.4 percentage points.

Thus, it can be assumed that the analysed hotel business subject uses aggressive methods of tax optimization, tax evasion, which can lead to serious financial losses in the form of 
additional taxation and penalties. Risk-oriented management of the tax portfolio allows you to diagnose the financial and property status of an economic entity depending on the changes in the composition of the tax portfolio and the level of tax risk allowed.

The use of tools to optimize the corporate portfolio of the hotel business subject to reduce tax expenses in the context of resource constraints is accompanied by an analysis of its effective implementation and the organization's development forecast in order to make the company management adopt an adequate effective solution.

\section{Conclusion}

1. One of the most important financial problems hotel business is facing at the moment is the shortage of working capital that can be solved by optimizing the tax portfolio. Optimization involves not only reducing the absolute business tax burden but also preserving the resources of the hotel in the conditions of tax risks. In general, the efficiency of tax portfolio optimizing is estimated by its goals achievement using limited resources available in the hotel.

2. The use of tax alternatives proves the desire of the legislator to introduce discretionary principles into the legislation on taxes and fees more actively. Such expansion in the public law system is a sign of time and the expression of objective laws of modern legal development.

3. The entrepreneurial activity of the hotel business is based on extraction of an ever increasing amount of profit. A significant part of it is reduced by the amount of tax payments. The taxpayers regulate their tax portfolio by any possible means. The authorities in some way contribute to this process by annually posting the average tax burden by industry on the official website of the Federal Tax Service, which is one of the criteria for conducting onsite inspections of economic entities [3]. As a rule, the majority of decision-makers tend to avoid the risk of participation in the tax audit when it comes to management of tax portfolio, especially field tax inspection.

4. The issues discussed and the recommendations formulated have made it possible for the hotel business companies to use them when calculating the tax burden, alternative use of various taxation systems and forecasting the economic consequences of the decision taken.

5. Organization's tax portfolio analysis, clarification of its structure, its external and internal determinants allow to consider the relation of the tax burden and tax risks of the organization, to take into account the composition of tax obligations, determine the amount of the tax potential and the nature of tax elections necessary for effective management of tax and financial risks of the organization

6. To manage the hotel's tax portfolio effectively it is necessary to look for new ways to optimize it; to keep abreast of new trends in tax legislation; to implement innovations on tax analysis improvement. The effectiveness of the hotel business entity grows as the professionalism of its tax portfolio managers increases.

7. The optimization methods used are individual in each organization that applies riskbased management to tax portfolio, but the fundamental factors are their integrated application and regular diversification due to the fact that the legislation is characterized by high volatility.

\section{References}

1. The Tax Code of the Russian Federation (Part One) of July 31, 1998 No. 146-FZ (as amended on July 18, 2017), http://www.consultant.ru/ 
2. The Tax Code of the Russian Federation (part two) of 05.08.2000 N 117-FZ (as amended on 03/04/2017), 221, http: //www.consultant.ru/

3. Order of the Federal Tax Service of Russia of 30.05.2007 N MM-3-06 / 333 "On approval of the Concept of the system of planning on-site tax inspections" (2012

4. A.N. Afanasenko, Finansi i kredit, 12(636), 49 (2015)

5. I.V. Frolova, T.G. Pogorelova, Modern Challenges and Realities of Economic Development of Russia, the materials of the II International Scientific and Practical Conference, 222 (2016)

6. I.V. Frolova, T.G. Pogorelova, Tax portfolio of the organization, Formation, analysis and management, 114 (2016)

7. I.V. Frolova, T.G. Pogorelova, Bulletin of the North Ossetian State University after Kostan Levanovich Khetagurov, 2, 161 (2016)

8. E. Cauble, Santa Clara Law Review, 53(2), 428, 445 (2013)

9. E. Satterthwaite, Queen's Law Journal, 63 (2016) http://ssrn.com/

10. I.V. Frolova, T.V. Matytsyna, T.G. Pogorelova, E.A. Likhatskaya, The 4th International Conference on Management and Technology in Knowledge, Service, Tourism \& Hospitality, Vladimir (2016)

11. I.V. Frolova, T.V. Matytsyna, A.U. Polenova, T.G. Pogorelova, N.U. Lebedeva, The 5th International Conference on Management and Technology in Knowledge, Service, Tourism \& Hospitality, Indonesia (2017)

12. Official site of the FSSS of the Russian Federation, http://www.gks.ru/ 